\title{
DIAGNOSA KESULITAN SISWA DALAM MENYELESAIKAN SOAL MATEMATIKA DAN UPAYA MENGATASINYA MENGGUNAKAN SCAFFOLDING
}

\author{
Ince D. Baun ${ }^{1}$, Yusak I. Bien², Alfonsia M. Abi ${ }^{3 *}$ \\ ${ }^{1}$ Mahasiswa Pendidikan Matematika STKIP Soe, ${ }^{2,3}$ STKIP Soe \\ *fonsaabi14@gmail.com
}

Diterima: 01 Mei 2020 Disetujui: 13 Juli 2020 Dipublikasikan: 31 Juli 2020

\begin{abstract}
ABSTRAK
Kesulitan siswa dalam menyelesaikan soal matematika adalah ketidakmampuan siswa dalam menyelesaikan soal matematika yang ditandai dengan adanya kesalahan. Penelitian ini bertujuan untuk mendiagnosa kesulitan siswa kelas VIII.F SMP Negeri 1 Amanuban Barat pada materi teorema Pythagoras. Subjek terdiri dari 17 orang. Penelitian yang digunakan adalah penelitian kualitatif dengan pendekatan studi kasus. Teknik pengumpulan data yang digunakan berupa observasi, tes dan wawancara sedangkan teknik analisis datanya mengikuti model Miles dan Huberman. Hasil diagnosa menyimpulkan siswa sulit dalam menyelesaikan soal matematika yang ditunjukkan dengan kurangnya ketelitian dalam menentukan ukuran pada gambar dan tidak mampu menarik kesimpulan. Proses pemberian scaffolding berdasarkan letak kesulitan yang dialami yaitu: (1) meminta siswa membaca kembali soal, (2) memberikan kesempatan kepada siswa untuk bernalar, (3) mengajukan pertanyaan arahan sehingga siswa mampu menggunakan konsep matematika yang sesuai, (4) meminta siswa merefleksikan jawaban yang telah dibuat sehingga dapat menemukan kesalahan dan kesulitan yang dialami, (5) meminta siswa memperbaiki pekerjaannya dan, (6) meminta siswa memeriksa kebenaran hasil pekerjaan. Keenam perlakuan scaffolding tidak berurut dalam mengatasi kesulitan siswa. Perlakuan yang berbeda ini mampu membantu mengurangi kesulitan siswa terutama pada konsep-konsep matematika yang telah dipelajari. Pemberian scaffolding secara terus menerus agar siswa mampu menyelesaikan soal matematika.
\end{abstract}

Kata kunci: diagnosa kesulitan, scaffolding, soal matematika.

\begin{abstract}
Student's difficulties in solving the problem of mathematics is a problem that causes students are not able to solve their difficulties of learning mathematics. The purpose of this study is to diagnose student's difficulties in learning about Pythagoras theorem of VIIIF SMP Negeri 1 Amanuban Barat. The subjects consist of 17 students. This study belongs to qualitative research with approach of case study. The instruments in this study are observation sheet, test, interview while for analyze the data use Miles and Huberman model. The study revealed that the students have less accurate in determining size of pictures and not able to make a conclusion. Based on students difficulties, to overcome those problems the researcher use the process of scaffolding to solve their problem in learning mathematics, such us: (1) asking student's to find their difficulties in mathematics, (2) giving students opportunity to think logically, (3) giving some instruction questions in order to student's are able to use the appropriate mathematics concept, (4) asking students to reflex their own answers to find their problem and difficulties, (5) asking student's to repair their result of test, and (6) asking student's to examine again their result of test. These six scaffolding treatments are not sequential in overcoming student difficulties. These different treatments can help reduce student difficulties, especially on mathematical concepts that have been learned. Provision of scaffolding continuously so students are able to solve math problems.
\end{abstract}

Keywords: diagnosis student's difficulty, the problem of mathematics, and scaffolding.

\section{Pendahuluan}

Matematika sebagai ilmu pengetahuan memiliki keunggulan dalam memecahkan berbagai persoalan kehidupan. Hal ini menjadikan matematika sebagai mata pelajaran wajib pada setiap jenjang pendidikan yang ada di Indonesia. Namun faktanya, banyak siswa masih kesulitan dalam mempelajari matematika terutama ketika menyelesaikan soal yang ditandai dengan adanya kesalahan. Menurut Hayinah, kesulitan belajar siswa adalah suatu kondisi dalam proses belajar mengajar yang ditandai 
dengan adanya hambatan-hambatan tertentu dalam mencapai tujuan belajar atau hasil belajar (Mustaqim, 2013).

Kesulitan yang dialami oleh siswa dalam menyelesaikan soal matematika merupakan timbal balik antara berbagai faktor yang mempengaruhinya. Secara umum faktor-faktor yang mempengaruhi kesulitan belajar dapat dikategorikan menjadi 2 yaitu faktor intern dan ekstern. Fakror intern adalah faktor yang ada dalam diri individu yang sedang belajar sedangkan faktor ekstern adalah faktor yang ada diluar individu (Slameto, 2013:54).

Berdasarkan hasil observasi dan wawancara di SMP Negeri 1 Amanuban Barat diperoleh informasi bahwa siswa masih kesulitan dalam menyelesaikan soal matematika terkait materi teorema Pythagoras. Hal ini ditunjukkan dengan hasil kerja siswa seperti pada Gambar 1.

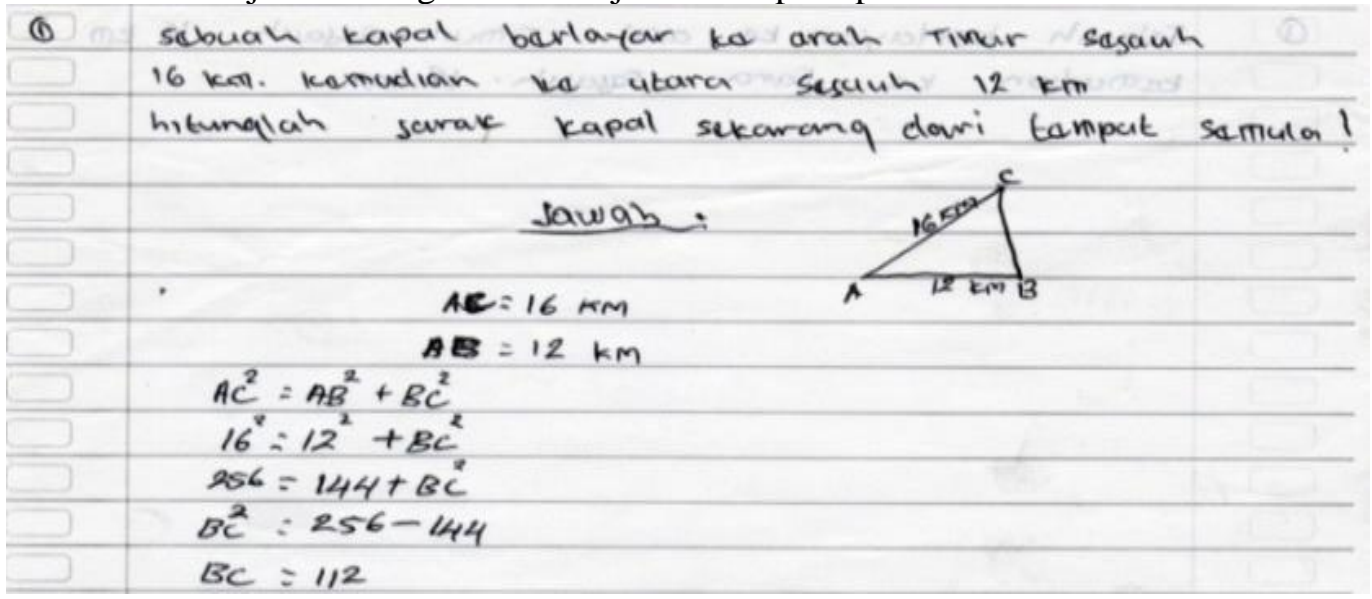

Gambar 1. Hasil Kerja Siswa

Dari gambar 1 dapat dilihat bahwa siswa: 1) tidak mampu merumuskan apa yang diketahui dan yang ditanyakan secara tertulis; 2) siswa kurang teliti dalam menentukan ukuran pada gambar; 3) tidak mampu dalam menarik kesimpulan. Oleh karena itu dilakukan analisis untuk mengetahui kesulitan siswa dalam menyelesaikan soal matematika pada materi teorema Pythagoras dan upaya mengatasinya dengan menggunakan scaffolding (pemberian bantuan) supaya kesulitan yang sama jangan terulang lagi pada materi yang lain.

Analisis kesulitan siswa dalam menyelesaikan soal matematika berkaitan dengan teorema Pythagoras bertujuan untuk menelusuri secara mendalam letak dan penyebab kesulitan siswa. Kesulitan dalam menyelesaikan soal matematika dikarenakan siswa kesulitan dalam merumuskan apa yang diketahui dan ditanyakan, kesulitan dalam menentukan ukuran pada gambar, kesulitan dalam menarik kesimpulan maka perlu adanya suatu scaffolding yang tepat untuk mengatasi kesulitan tersebut. Vygotsky menjelaskan scaffolding sebagai bentuk bantuan yang tepat untuk dilakukan ketika interaksi belajar sedang terjadi pada saat siswa menyelesaikan soal atau tugas lainnya (Hasan, 2015).

Scaffolding yang diberikan kepada siswa dapat berupa gambar, petunjuk, motivasi, arahan, peringatan, menguraikan soal-soal ke dalam langkah-langkah pemecahan, memberikan contoh dan tindakan lain yang memungkinkan siswa dapat belajar secara mandiri. Pemberian bantuan ini bertujuan agar siswa mampu menyelesaikan soal-soal matematika yang diberikan secara mandiri. Scaffolding tidak hanya dilakukan secara spontan atau langsung akan tetapi seorang guru harus mengetahui karakter dan soal yang dihadapi siswa, sehingga scaffolding yang diberikan dapat mengatasi soal yang dialami siswa.

\section{Metode Penelitian}

Jenis penelitian yang digunakan dalam penelitian ini adalah penelitian kualitatif dengan pendekatan studi kasus. Penelitian ini dilaksanakan di SMP Negeri 1 Amanuban Barat pada semester genap tahun ajaran 2017/2018. Instrumen yang digunakan dalam penelitian ini berupa observasi, tes dan 


\section{Range: Jurnal Pendidikan Matematika Vol. 2 No. 1 Tahun 2020 Ince D. Baun, dkk}

wawancara. Tes yang digunakan dalam penelitian ini adalah tes diagnosa kesulitan siswa dalam menyelesaikan soal matematika sebanyak 3 soal uraian. Sumber data dalam penelitian ini adalah siswa kelas VIIIF SMP Negeri 1 Amanuban Barat sebanyak 17 orang. Teknik pengumpulan data yang digunakan adalah observasi, tes dan wawancara. Teknik analisis data yang digunakan dalam penelitian ini adalah analisis data kualitatif mengikuti model Miles dan Huberman. Uji keabsahan data yang digunakan adalah metode triangulasi teknik.

\section{Hasil Penelitian dan Pembahasan}

Hasil diagnosa kesulitan siswa dalam menyelesaikan soal matematika pada materi teorema Pythagoras dapat disajikan pada Tabel 1.

Tabel 1. Nilai Hasil Tes Diagnosa Kesulitan Siswa

\begin{tabular}{lcccc}
\hline \multirow{2}{*}{ Soal yang dijumpai } & \multicolumn{3}{c}{ Nomor Soal } & Rata- \\
\cline { 2 - 3 } & $\mathbf{1 ( \% )}$ & $\mathbf{2 ( \% )}$ & $\mathbf{3 ( \% )}$ & Rata \\
\hline Kurang teliti ketika menentukan ukuran pada gambar & 5,88 & 0,00 & 0,00 & 1,96 \\
Kurang teliti dalam menggunakan tanda operasi yang dipakai & 0,00 & 52,94 & 47,06 & 33,33 \\
Kurang memahami materi prasyarat(materi akar) & 23,53 & 82,35 & 76,47 & 60,78 \\
Kurang memahami soal matematika sehingga sulit dalam & 5,88 & 11,76 & 35,29 & 17,65 \\
menggunakan langkah-langkah penyelesaian & 70,59 & 76,47 & 70,59 & 72,55 \\
Tidak mampu menarik kesimpulan & & &
\end{tabular}

Tabel 1 menunjukkan rata-rata siswa kurang teliti dalam menentukan ukuran pada gambar, kurang teliti dalam menggunakan tanda operasi yang dipakai, kurang memahami materi prasyarat (materi akar) serta kurang memahami soal matematika. Ini mengakibatkan siswa sulit dalam menggunakan langkah-langkah penyelesaian dan tidak mampu menarik kesimpulan. Kesulitan siswa ini dapat diatasi dengan pemberian scaffolding berupa membaca kembali soal, memberikan kesempatan untuk bernalar, mengajukan pertanyaan arahan sehingga mampu menggunakan konsep matematika yang sesuai, merefleksi jawaban yang telah dibuat sehingga dapat menemukan kesalahan dan kesulitan yang dialami, memperbaiki pekerjaan dan memeriksa kebenaran hasil pekerjaan. Perlakuan tersebut di atas didasarkan pada kesulitan yang dialami oleh siswa.

Hasil pekerjaan S1 menunjukkan bahwa S1 kurang memahami materi prasyarat (materi akar) dan kurang teliti dalam menentukan tanda operasi yang dipakai serta tidak mampu menarik kesimpulan, seperti pada Gambar 2. Hasil observasi menunjukkan S1 kurang terlibat dalam menyelesaikan soal matematika disebabkan karena tidak konsentrasi pada saat proses belajar mengajar berlangsung. Berdasarkan hasil wawancara S1 mengalami kesulitan dalam memahami materi prasyarat (materi akar) sehingga kurang mengerti pada cara menghitung akar, kurang memahami konsep matematika sehingga mengakibatkan kesalahan dalam menggunakan tanda operasi yang dipakai. Scaffolding yang diberikan berupa mengingat kembali materi perpangkatan misalkan $a^{2}=a x a$ maka $\sqrt{a}=a$ jika $25=5^{2}$ maka $\sqrt{25}=5$ kemudian S1 menyelesaikan soal yang sama dan membaca kembali soal yang ada agar dipahami sehingga tidak sulit dalam menyelesaikan serta dapat menentukan kesimpulan akhir. Dengan adanya pemberian scaffolding mampu membantu mengurangi kesulitan siswa dalam memahami konsepkonsep matematika terutama pada materi akar, memahami konsep sehingga teliti menggunakan tanda operasi yang dipakai dan mampu menarik kesimpulan. 


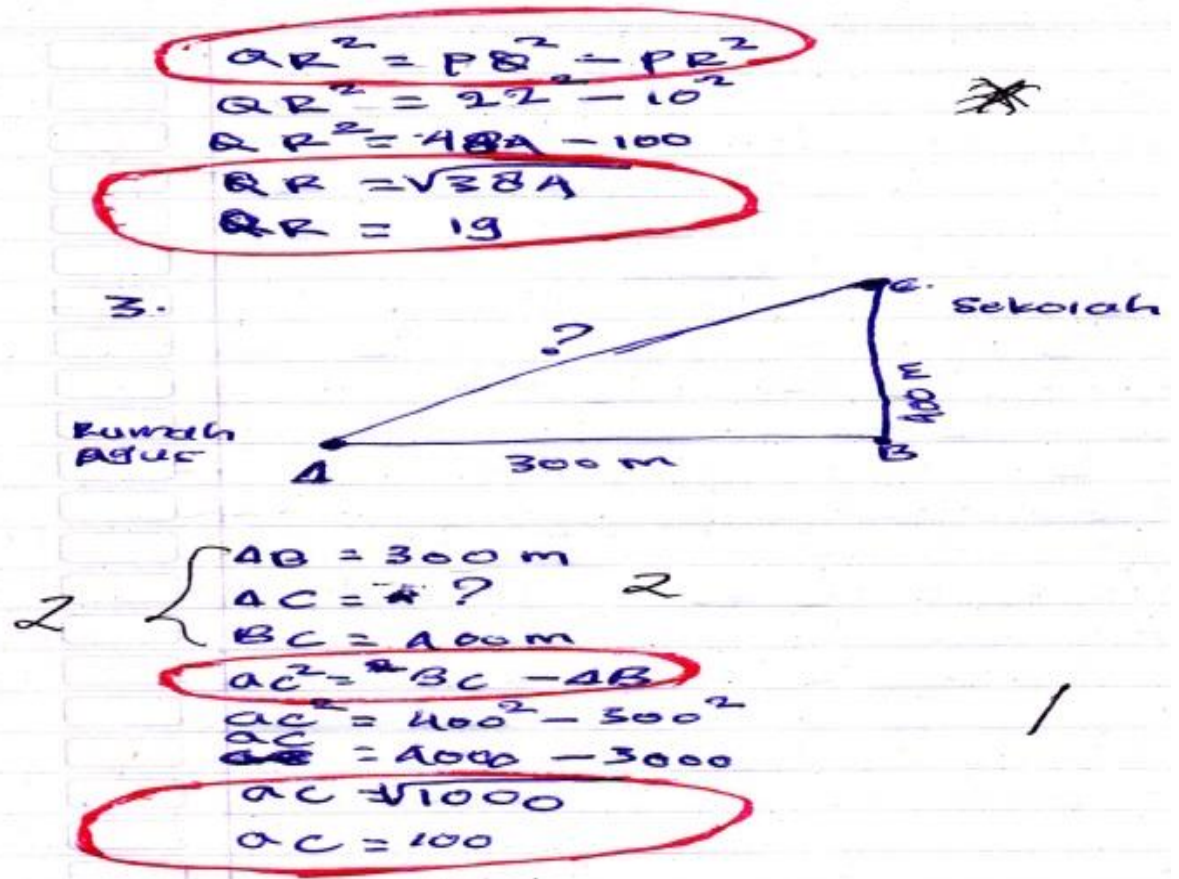

Gambar 2. Hasil Kerja Siswa S1

Hasil pekerjaan S4 menunjukkan bahwa S4 kurang memahami soal sehingga sulit dalam menggunakan langkah-langkah penyelesaian, kurang memahami materi prasyarat (materi akar), kurang teliti dalam menentukan tanda operasi yang dipakai dan tidak mampu menarik kesimpulan. Hasil observasi menunjukkan S4 memiliki respon yang kurang baik ketika menyelesaikan soal matematika akibatnya sulit dalam memahami konsep matematika. Hasil wawancara dengan S4 yaitu mengalami kesulitan pada kurang memahami materi akar dan tidak mampu mencakar hal ini disebabkan karena tidak menghafal perkalian, disisi lain S4 kurang memahami soal matematika sehingga sulit menggunakan langkah-langkah penyelesaian disebabkan karena tidak mempunyai buku cetak sehingga tidak bisa melihat cara kerja dan tidak memahami konsep matematika serta tidak dapat menarik kesimpulan karena S4 yakin bahwa jawaban yang telah dikerjakan sudah benar sehingga tidak perlu menarik kesimpulan. Adapun pemberian scaffolding yaitu membaca kembali soal, mengingat kembali materi pangkat dua agar dapat mengerti tentang apa yang telah diberikan, misalnya $6^{2}=6 \times 6=36$, maka akar dari $\sqrt{36}=6$ kemudian menyelesaikan soal yang sama dan memperbaiki pekerjaan yang telah dikerjakan. Pemberian scaffolding mampu membantu siswa teliti dalam menggunakan langkah-langkah penyelesaian, memahami materi prasyarat, teliti dalam menggunakan tanda operasi yang dipakai dan mampu menarik kesimpulan. Seperti tampak pada Gambar 3.

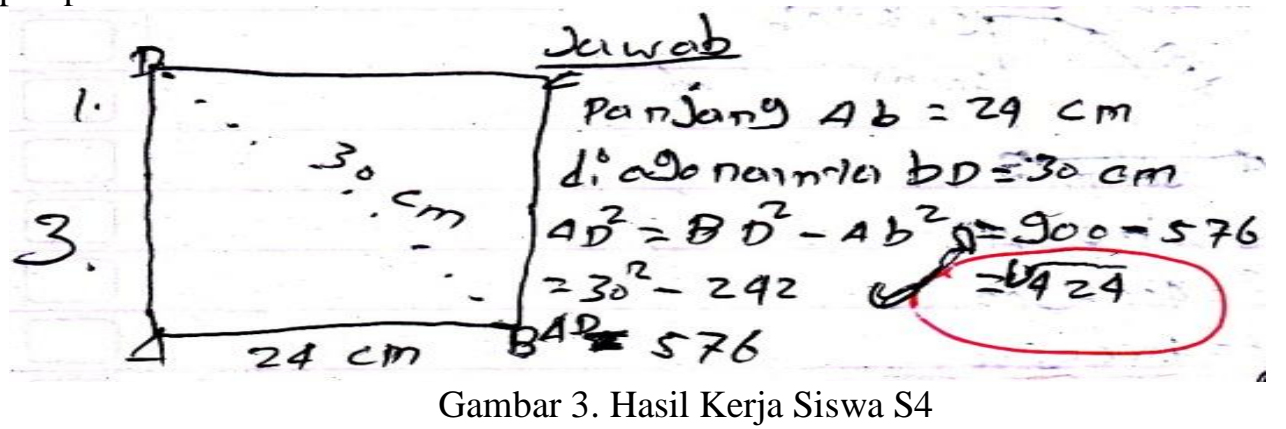

Gambar 3. Hasil Kerja Siswa S4 


\section{Range: Jurnal Pendidikan Matematika Vol. 2 No. 1 Tahun 2020 Ince D. Baun, dkk}

Hasil pekerjaan S9 menunjukkan kurang teliti pada materi prasyarat (materi akar) sehingga sulit pada bagian hasil akhir dan kurang teliti ketika menarik kesimpulan. Hasil observasi menunjukkan S9 kurang bekerja sama dengan teman dekatnya ketika proses pembelajaran berlangsung. Hasil wawancara dengan S9 yaitu mampu memahami konsep yang diberikan namun kurang teliti pada bagian hasil akhir ketika menghitungnyadan kurang teliti pada saat menarik kesimpulan ini disebabkan karena S9 asyik bercerita dengan teman sehingga tidak konsentrasidan kesalahan pada saat mencakar untuk itu upaya pemberian scaffolding dalam menyelesaikan soal matematika pada materi teorema Pythagoras yaitu membaca kembali soal yang ada dan memperbaiki pekerjaan yang telah dikerjakan serta mengecek kembali hasil pekerjaan sehingga hasil yang dikerjakan sudah benar. Pemberian scaffolding mampu membantu siswa mengurangi kesulitan ketika memahami materi prasyarat dan teliti ketika menarik kesimpulan. Hasil kerja siswa tampak pada Gambar 4.

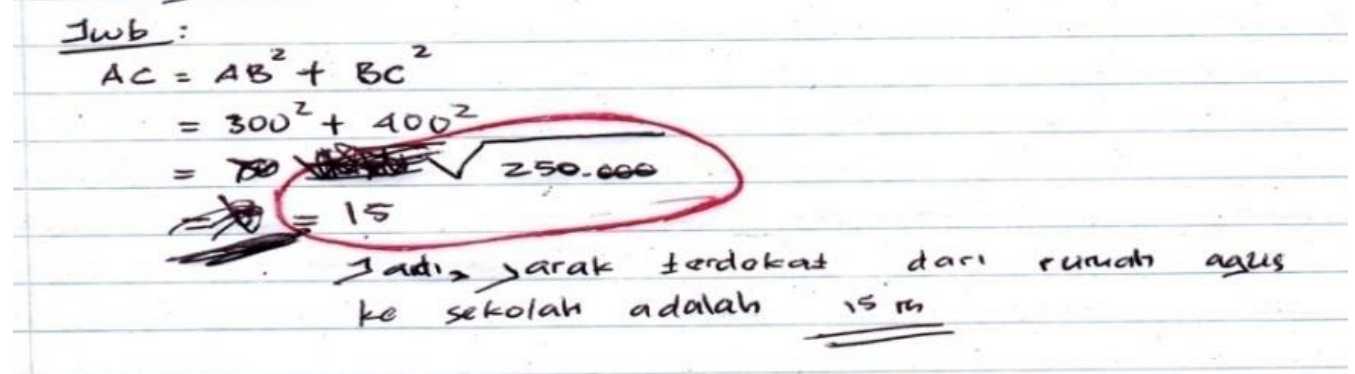

Gambar 4. Hasil Kerja Siswa S9

Hasil pekerjaan S10 menunjukkan kurang teliti dalam menentukan tanda operasi yang dipakai disebabkan karena kurang memahami konsep matematika, kurang memahami materi prasyarat (materi akar), kurang memahami soal matematika sehingga sulit menggunakan langkah-langkah penyelesaian dan tidak mampu menarik kesimpulan, hal ini sesuai Gambar 5. Hasil observasi menunjukkan S10 kurang baik dalam menyelesaikan soal matematika akibatnya aktivitas siswa ketika belajar dikelas rendah dan kurangnya interaksi antara siswa dengan guru disaat proses pembelajaran berlangsung. Hasil wawancara dengan S10 yaitu mengalami kesulitan karena tidak belajar dan tidak memperhatikan ketika proses pembelajaran berlangsung sehingga tidak memahami soal dan sulit dalam menggunakan langkah-langkah penyelesaian disebabkan karena menyalin hasil pekerjaan dari teman dan tidak mampu menarik kesimpulan disebabkan karena tidak terbiasa dalam menarik kesimpulan. Adapun upaya pemberian scaffolding adalah membaca kembali soal dan memeriksa kebenaran dari hasil pekerjaan serta menyelesaikan soal sesuai prosedur dan urutan yang jelas dan sesuai dengan petunjuk yang ada dalam soal. Scaffolding yang diberikan mampu membantu S10 teliti dalam menggunakan tanda operasi yang dipakai, memahami materi prasyarat, teliti dalam menggunakan langkah-langkah penyelesaian dan ketika menarik kesimpulan.

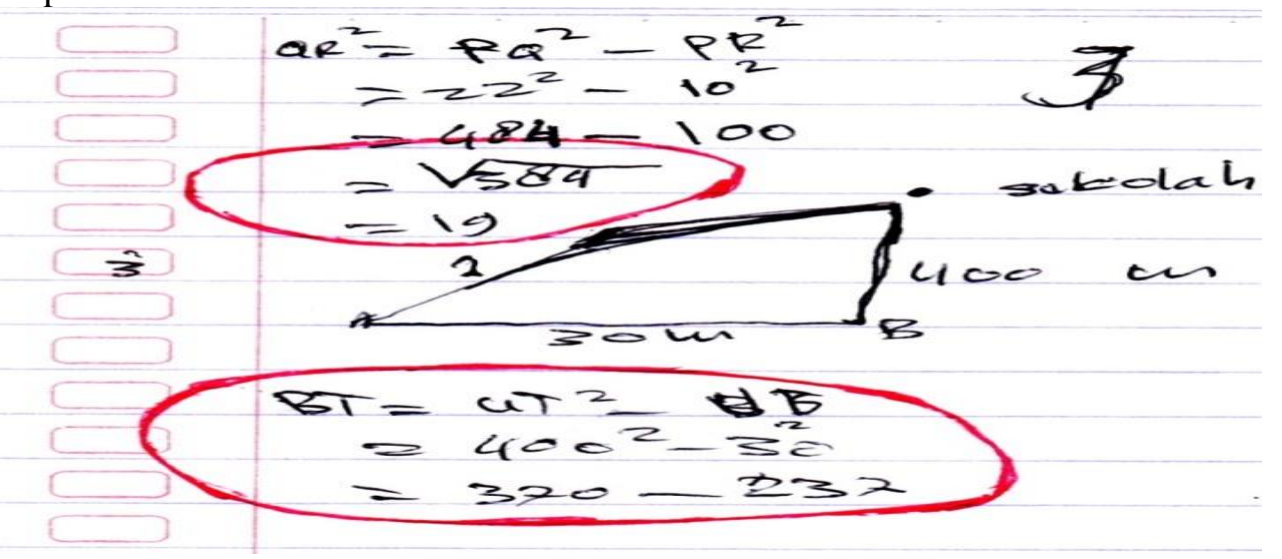

Gambar 5. Hasil Kerja Siswa S10 
Berdasarkan perlakuan terhadap hasil diagnosa kesulitan siswa, scaffolding menjadi pilihan dalam mengatasi kesulitan dengan pembiasaan. Kesulitan siswa dalam menyelesaikan soal matematika pada tahap membaca kembali soal dengan baik dan teliti, merefleksikan jawaban yang telah dibuat sehingga dapat menemukan kesulitan yang dialami, memperbaiki dan memeriksa kembali hasil pekerjaan. Kesulitan yang dialami siswa dapat diketahui dari ketidakmampuan siswa dalam mengerjakan soal, diantaranya ketelitian ketika menentukan ukuran pada gambar, ketelitian dalam menggunakan tanda operasi yang dipakai, kemampuan memahami materi prasyarat (materi akar) dan kemampuan memahami soal matematika serta menarik kesimpulan. Hal ini sesuai dengan penelitian Hasan (2015) mengatakan bahwa penggunaan scaffolding untuk mengatasi kesulitan menyelesaikan soal matematika pada tahap memahami soal (understanding the problem) adalah meminta siswa untuk membaca kembali soal dengan baik dan teliti. Persoalan yang menjadi penyebab kesulitan siswa dalam menyelesaikan soal matematika berawal dari siswa masih belum memahami soal matematika sehingga terdapat kesulitan dalam menyelesaikan soal matematika. Oleh karena itu, perlu adanya scaffolding kepada siswa agar dapat menyelesaikan soal tersebut sehingga kesulitan mereka tidak menyebabkan kesalahan. Kesalahan yang dapat dilakukan oleh siswa berdasarkan kesulitan-kesulitan ini dapat berupa kesalahan memahami konsep abstrak, pelaksanaan prosedur, serta memahami fakta yang disajikan dalam soal.

Scaffolding yang diberikan dapat membantu mengurangi kesulitan siswa dalam menyelesaikan soal matematika secara mandiri. Pemberian scaffolding secara terus menerus kepada siswa untuk dapat mengatasi kesulitan yang dialami. Setiap kesulitan memiliki cara penanganan dengan scaffholding yang berbeda. Berbeda yang dimaksud adalah langkah-langkah pemberian scaffholding yang tidak berurut. Proses pemberian scaffolding berdasarkan letak kesulitan. Seperti yang diungkapkan oleh Susilo (2019) bahwa pemberian scaffholding berdasarkan kemampuan anak akan memberikan pengaruh yang berbeda-beda tergantung kemampuan matematika anak itu sendiri. Kesulitan yang sering dialami siswa sesuai dengan tabel 1 dengan pemberian scaffholding yang sesuai tampak pada tabel 2 .

Tabel 2. Jenis Kesulitan dan Jenis Scaffholding yang diberikan

\section{Kesulitan Scaffholding}

\begin{tabular}{|c|c|}
\hline $\begin{array}{l}\text { Sulit memahami soal terutama soal } \\
\text { berupa gambar karena kurang teliti } \\
\text { Sulit menentukan operasi yang tepat yang } \\
\text { digunakan menyelesaikan soal } \\
\text { Sulit mengingat dan memahami } \\
\text { memahami materi prasyarat yang } \\
\text { berkaitan dengan soal } \\
\text { Sulit dalam menyajikan langkah-langkah } \\
\text { penyelesaian } \\
\text { Sulit melakukan penarikan kesimpulan }\end{array}$ & $\begin{array}{l}\text { 1. meminta siswa membaca kembali soal, } \\
\text { 2. memberikan kesempatan kepada siswa untuk } \\
\text { bernalar, } \\
\text { 3. mengajukan pertanyaan arahan sehingga siswa } \\
\text { mampu menggunakan konsep matematika yang } \\
\text { sesuai, } \\
\text { 4. meminta siswa merefleksikan jawaban yang telah } \\
\text { dibuat sehingga dapat menemukan kesalahan dan } \\
\text { kesulitan yang dialami, } \\
\text { 5. meminta siswa memperbaiki pekerjaannya dan, } \\
\text { 6. meminta siswa memeriksa kebenaran hasil pekerjaan }\end{array}$ \\
\hline
\end{tabular}

Semua tahapan scaffholding diberikan kepada siswa. Hanya saja urutannya akan sedikit berbeda dilihat dari setiap kesulitan yang dihadapi siswa dan jika dibutuhkan, langkah-langkahnya akan berulang. Seperti pada kesulitan siswa dalam melakukan penarikan kesimpulan, siswa hanya melakukan refleksi jawaban lalu menarik kesimpulan. Ini berlaku untuk siswa yang tidak memiliki kesulitan memahami soal dan memilih operasi atau konsep apa yang dibutuhkan dalam menyelesaikan soal. Tetapi bagi siswa yang memiliki kesulitan yang kompleks, maka keenam langkah scaffholding harus diberlakukan. Scaffolding merupakan suatu cara yang dapat digunakan guru untuk meminimalis kesulitan siswa dalam belajar matematika ataupun dalam pemecahan masalah matematika (Chairani, 2015) 


\section{Range: Jurnal Pendidikan Matematika Vol. 2 No. 1 Tahun 2020 Ince D. Baun, dkk}

Pemberian scaffholding membantu siswa memamahi soal lebih baik. Siswa lebih memahami materi prasyarat apa yang digunakan untuk membantu mereka menyelesaikan soal yang kemudian dituangkan ke dalam langkah-langkah untuk menemukan solusi. Ketika kesulitan-kesulitan ini teratasasi karena pemberian scaffholding maka untuk melakukan penarikan kesimpulan siswa tidak lagi mengalami kesulitan. Ini sejalan dengan penelitian Mustaqim (2013) yang mengatakan bahwa pemberian scaffolding di bagian sulit yang dialami siswa dapat mengurangi/menghilangkan kesulitan siswa. Agar scaffolding dapat berjalan dengan benar dan efektif maka siswa perlu mendapatkan pelatihan dan pengalaman yang cukup (Sutiarso, 2009).

\section{Kesimpulan}

Berdasarkan hasil penelitian, disimpulkan bahwa scaffolding menjadi referensi dalam menyelesaikan soal matematika pada materi teorema Pythagoras. Kesulitan yang dialami siswa dapat diketahui dari ketidakmampuan siswa dalam mengerjakan soal, diantaranya kurang teliti dalam menentukan ukuran pada gambar, kurang teliti dalam menggunakan tanda operasi yang dipakai, kurang memahami materi prasyarat (materi akar), kurang memahami soal matematika sehingga sulit dalam menggunakan langkah-langkah penyelesaian dan ketidakmampuan dalam menarik kesimpulan. Scaffolding yang dilakukan untuk mengatasi kesulitan siswa dalam menyelesaikan soal matematika adalah: 1) meminta siswa membaca kembali soal, 2) memberikan kesempatan kepada siswa untuk bernalar, 3) mengajukan pertanyaan arahan sehingga siswa mampu menggunakan konsep matematika yang sesuai, 4) meminta siswa merefleksi jawaban yang telah dibuat sehingga dapat menemukan kesalahan dan kesulitan yang dialami, 5) meminta siswa memperbaiki pekerjaannya, 6) meminta siswa memeriksa kebenaran hasil pekerjaan. Keenam scaffolding membantu mengurangi kesulitan siswa dalam menyelesaikan soal matematika.

Saran yang dapat diberikan dari penelitian ini adalah kepada guru mata pelajaran agar perlu mengetahui terlebih dahulu kesulitan-kesulitan siswa untuk kemudian diberikan scaffolding. Pemberian scaffolding secara terus menerus kepada siswa untuk dapat mengatasi kesulitan dalam menyelesaikan soal matematika. Penelitian ini memberikan remediasi untuk kesulitan yang dilakukan siswa agar semakin paham dengan letak kesulitan yang dialami dan pemberian scaffolding dapat membantu siswa dalam mengatasi kesulitan.

\section{Daftar Pustaka}

Chairani, Z. (2015). "Scaffholding dalam Pembelajaran Matematika". Math Didactic: Jurnal Pendidikan Matematika, 1 (1): 39-44.

Hasan, B. (2015). "Penggunaan Scaffolding untuk Mengatasi Kesulitan Menyelesaikan Soal Matematika".Jurnal APOTEMA, 1(1):88-98.

Mustaqim. (2013). "Proses Scaffolding Berdasarkan Diagnosis Kesulitan Siswa dalam Menyelesaikan Soal Program Linear dengan Menggunakan Mapping Mathematic". Jurnal Pendidikan Sains, 1(1): $72-78$.

Slameto. (2013). Belajar dan Faktor-faktor yang Mempengaruhinya. Jakarta: Rineka Cipta.

Susilo, C. Z. (2019). "Penggunaan Scaffholding Untuk Memperbaiki Kesalahan Siswa SMP dalam Menyelesaikan Masalah Matematika”. Ed-Humanistics, 04(1): 502-508.

Sutiarso, S. (2009). "Scaffholding dalam Pembelajaran Matematika". Prosiding Seminar Nasional Penelitian, Pendidikan dan Penerapan MIPA Fakultas MIPA Universitas Negeri Yogyakarta.

Vygotsky, L. S. (1978). Mind in Society: The Development of Higher Psychological Processes. In M. Cole, V. John Steiner, S. Scriber and E. Souberman (eds). Cambridge, M.A.: Harvard University. 